\title{
ESTUDO INTEGRADO GEOFÍSICO HIDROGEOLÓGICO DO SUBGRUPO ITARARÉ, MUNICÍPIO DE TIETÊ/SP
}

\author{
Henrique Angelo Piovesan Dal Pozzo \\ Orientador: Dr. Vagner Roberto Elis (IAG-USP) \\ 147 p - Dissertação (Mestrado) - Defesa 29.04.2003
}

RESUMO. Neste trabalho foram efetuados levantamentos geofísicos com os métodos da eletrorresistividade e polarização induzida para caracterizar os aquíferos sedimentares do subgrupo Itararé na região de Tietê, SP, quanto aos aspectos litológicos, geométricos e hidrodinâmicos. A interpretação de sondagens elétricas verticais integrada com informações de geologia de superfície e dados de poços tubulares permitiu identificar as camadas sedimentares de diferentes litologias, intrusões de rochas básicas e a profundidade do embasamento cristalino. A elaboração de seções geoelétricas estratigráficas evidenciaram a geometria da formação Tietê, aquífero principal da área, depositada por sistemas deltaicos que progradaram sobre um paleo vale do subgrupo Itararé. Os parâmetros resistência transversal e transmissividade mostraram uma excelente correlação, a partir da qual foi elaborada um mapa de transmissividade estimada que possibilitou avaliar a potencialidade dos aquíferos em toda a área de estudo. Os resultados obtidos nesta pesquisa mostram que a metodologia utilizada é adequada ao estudo de aqǘferos sedimentares.

ABSTRACT. This work integrates geophysical investigations involving electrical resistivity and induced polarization methods with the principal objective of characterizing the aquifers within the sediments of the Itararé Subgroup in the Tietê region, SP. At also puts an emphasis to such aspects as lithologies, geometries and hydrodynamics of the aquifer under consideration. The interpretation of vertical electrical sounding, integrated with surface and borehole information has permitted to identify layers of various sedimentary formations with different lithologies, basic intrusive rocks and the depth to the crystalline basement. The resulting geo-electric/estratigraphic section revealed the geometry of the Tietê Formation, the principal aquifer of the study area, which is deposited in a delta system propagated in a paleo-valley of the Itararé Subgroup. The transversal resistance and transmitivity parameters have show an excellent correlation and were employed in preparing the estimated transmitivity map. This map has permitted to evaluate the potential of each aquifer, in terms of groundwater exploration, within the area under investigation. The results obtained has proved the combination of geophysical and other related disciplines utilized for this study are adequate for aquifer mapping and evaluation in sedimentary terrain. 